\title{
Arming the Outlaws: On The Moral Limits of the Arms Trade
}

If, not unreasonably, we were to follow Albert Camus in assessing the relative urgency of philosophical questions by reference to the actions that they entail, it is likely that those surrounding the international arms trade would rank highly. "I have never seen anyone die for the ontological argument", Camus observed, dismissing its significance (Camus, 2000 [1942], p. 11). But countless people have died as a result of states approving or promoting the sale of weapons abroad. It is somewhat surprising, then, that the women and men whose job it is to think carefully about ethical issues have largely bypassed the subject. Political philosophers have devoted varying degrees of attention to related and adjacent questions about the justice of war (Fabre, 2014; McMahan, 2009), the morality of markets (Sandel, 2012; Satz, 2010), the private ownership of firearms (DeGrazia, 2016; Lafollette, 2000), and the normative dimensions of international commerce more generally (Christensen, 2017; James, 2012; Risse, 2007), but the arms trade itself has been almost entirely ignored. ${ }^{1}$ There is, of course, no paucity of social-scientific literature exploring empirical issues relating to the changing dynamics of international arms markets (Stohl and Grillot, 2009; Tan, 2010), but the moral concerns that draw so much attention to the arms trade in the first place have been neglected. This paper contributes to resetting the balance. In doing so, it joins a 
growing body of literature that seeks to answer a range of overlooked questions at the margins of just war theory. ${ }^{2}$

From a normative perspective, the most politically salient question about the international arms trade concerns its scope, or moral limits. There are three sets of scope-restrictions that might be placed on the arms trade: restrictions on what can be sold; restrictions on who can participate; and restrictions on what can be sold to certain participants. (The third category is relevant because we might think that certain products should not be sold to certain parties, even if the latter should not be excluded from the market altogether.) In this article, I consider the second set of scope-restrictions: restrictions on who can participate. ${ }^{3}$ It is the putative failure of politicians to appropriately limit the scope of the arms trade in this dimension that elicits the most vociferous opposition to international arms transfers. States regularly authorize the sale of weapons to outlaw states that, critics maintain, should be excluded from the market. (By an "outlaw state", I mean an oppressive regime that violates the basic rights of its own citizens, or an aggressive regime that wrongfully threatens the security of outsiders.) When I began writing this paper, the British government was under fire for its continued provision of weapons to Saudi Arabia, a country that had recently been condemned by the UN for its indiscriminate aerial attacks on schools, hospitals, and other forms of civilian infrastructure in Yemen (MacAskill, 2016). And the government has also recently been rebuked for selling arms to regimes guilty of abusing their own citizens. At the outset of the Arab 
Spring, the British authorities revoked export licenses covering sales to several Arab countries engaged in the violent repression of civilian protesters (Quinn and Booth, 2011), but they have been criticized for continuing to supply weapons to a range of countries about which the Home Office has the "most serious [and] wide-ranging human rights concerns" (Townsend and Boffey, 2014).

Weapons transfers to outlaw states typically contribute to the infliction of wrongful harms in a number of ways. They provide the tools with which domestic security forces coerce, maim, and kill, and with which national armies aggress against outsiders; they increase the power of the state relative to internal dissidents; and they increase the power of the state relative to members of the international community (Christensen, 2015, p. 34). Consequently, there is a general presumption against arming such states; the provision of arms to oppressive and aggressive regimes is prima facie wrongful. When a state provides weapons to such regimes, its status as a society in good standing in the international community is called into question. If it is to preserve that status, it must prove that its actions can be justified. This is something that Britain - along with other major arms exporters, such as the United States - has repeatedly failed to do.

But can the presumption against arming oppressive and aggressive regimes sometimes be overturned? And, if so, under what conditions could the justificatory burden be met? According to the argument that I want to consider here, outlaw states can have legitimate security interests, and transferring weapons to these states 
can be an appropriate way of promoting those interests. Weapons enable governments to engage in wrongful oppression and aggression, but they also enable them to fend off predators in a manner that can be beneficial to their citizens. It clearly does not follow from the fact that a state is oppressive or aggressive that it will never be a victim of wrongful aggression, and while an outlaw state's primary aim in repelling such aggression will often be the preservation of its own power, its defensive manoeuvres will sometimes also serve its citizens' interests. In short, supplying weapons to outlaw states may sometimes contribute to the protection of innocents.

We should note immediately that while supporting an outlaw state by supplying weapons may contribute to the protection of its innocent citizens, supplying weapons is one mode of support among several, and, under many circumstances, it will be a suboptimal approach. Any evaluation of a proposed arms transfer to an outlaw state must take a comparative form. Whether such a transfer can be justified will depend, inter alia, on how it fares relative to other actions that could be taken instead. If an arms transfer is expected to produce worse outcomes than alternative available options, then it will not be permissible. ${ }^{5}$

Comparative evaluation of available modes of intervention must proceed on a case by case basis, but certain considerations can be expected to consistently tell against the provision of arms (which is not to say that arms transfers will not be the best option, all-things-considered). Most obviously, arms transfers provide outlaw 
states with tools that can be used for oppressive and aggressive ends; other types of support lack this feature. Another distinctive shortcoming is the problem of "leakage". Outlaw states may pass on weapons to third parties, or be unable to ensure the security of stockpiles. The risk of stockpiles being looted is especially high in times of crisis (Stohl and Grillot, 2009, p. 100; and, relatedly, Pattison, 2015, pp. 460-61).

But there is one consideration that can be expected to tell in favour of providing arms (which is not to say that arms transfers will be the best option, allthings-considered), namely, providing arms may be less costly to the intervener than other modes of support, such as sending troops. Sending troops exposes interveners to an immediate risk of severe physical harm, while sending weapons does not. Sending weapons rather than troops may increase the risk of harm to others (either to the intended beneficiaries of the intervention or to third parties), but this may sometimes be permissible. It may be fairer for the largest costs of an intervention to be borne by those whose interests it is intended to serve (McMahan, 2010).

In the next two sections of this paper, I show how, and under what conditions, arming an outlaw state can be justified. I begin by considering arms transfers to oppressive regimes, and then move on to consider arms transfers to aggressive regimes. I am motivated not by a desire to vindicate the arms transfers to outlaw states in which our governments regularly engage, nor by mere philosophical curiosity, but rather by the importance of demonstrating just how 
difficult it is to justify such transfers - just how special the circumstances have to be and, therefore, how rarely these transfers will in fact be permissible. While any activists reading this article may be troubled by my willingness to concede that there are conditions under which arms sales to outlaw states can be justified, they can perhaps take solace in the fact that state officials and arms company executives involved in those sales will struggle to draw any comfort or reassurance from anything that I have to say.

\section{Oppressive Regimes}

Let us start by considering a case in which an oppressive regime is a victim of wrongful aggression.

Oppressors: an oppressive regime (the Incumbent) is vulnerable to being overthrown by vicious insurgents or the invading army of a rival state (the Challenger) whose rule promises to be even more despotic than the status quo. ${ }^{6}$ If we withhold weapons from the Incumbent, we will undermine its ability to wage a just defensive war that would serve the security interests of its citizens. Those interests cannot be served (as effectively, or without imposing far greater costs on us, the intervener) by other means.

In such a scenario, it seems, intuitively, that the general presumption against arming oppressive regimes is suspended. When the conditions I have described are satisfied, it will likely be said that we are permitted to transfer arms (the permission to arm 
claim), or even that we have a duty to transfer arms (the duty to arm claim). Each of these claims has two variants, which are distinguished by the type of arms transfer to which they refer. Notice that we can distinguish between two types of arms transfer: Foreign Military Sales (which are sales made by a government) and Direct Commercial Sales (which are sales made by a private firm) (Stohl and Grillot, 2009, p. 52). Thus, the permission to arm claim could mean either that (i) the state is permitted to engage in Foreign Military Sales (i.e. it is permitted to sell weapons to the Incumbent), or that (ii) the state is permitted to sanction Direct Commercial Sales (i.e. it is permitted to grant an export license allowing private firms within its jurisdiction to sell weapons to the Incumbent). Similarly, the duty to arm claim could mean either that (iii) the state has a duty to sell weapons to the Incumbent, or that (iv) the state has a duty to issue an export license (if one is sought). While they have intuitive force, these claims might be resisted in a number of ways.

One possible objection appeals to the distinction between doing and allowing harm (Pattison, 2015, pp. 458, 460, 464). It might be said that if a state transfers weapons to the Incumbent (in any of the ways described in claims (i)-(iv)), it does harm by contributing to the preservation of an oppressive status quo, whereas if a state withholds weapons, it merely allows harm to occur. It might then be argued that, at least if the relevant harms do not differ too greatly in size, doing harm is worse than allowing harm, and that if we are forced to choose between the two, we must choose the latter. This strategy raises two questions, which correspond to two 
of its key claims. First, is it really true that a state that exports weapons to the Incumbent thereby inflicts harm? And, second, is it really true that a state that withholds weapons from the Incumbent merely allows harm?

Consider the first question. One might suggest that an exporting state does not do harm when it transfers weapons to the Incumbent, for harm is a comparative concept - it involves making someone worse off than they were previously, or could otherwise have been - and, by transferring weapons, the exporting state does not make anyone worse off in either of these ways; rather, it contributes to the maintenance of the status quo, and to making the oppressed better off than they would be if the Challenger secured power. But this line of argument is defeated by a number of independent considerations. First, we do not have to conceive of harm in comparative terms. There are plausible non-comparative accounts that understand harms as absolute states, "a list of evils like broken limbs, disabilities, episodes of pain, significant losses, [and] death" (Shiffrin, 1999, p. 123). Second, it should not be assumed that the set of individuals that would be oppressed by the Challenger and the set of individuals that are oppressed by the Incumbent are coterminous: there may be some people who are oppressed by the Incumbent who would not be oppressed by the Challenger, even though the Challenger would be more oppressive overall. A related problem is that there might be some people who are oppressed by the Incumbent, and who would be oppressed by the Challenger, but who would be oppressed to a lesser degree by the Challenger. These people are made worse-off if 
we arm the Incumbent and thereby enable it to fend off the Challenger. So, the first key claim in the argumentative strategy under scrutiny - a state inflicts harm by transferring weapons to the Incumbent - remains intact (at least when certain conditions are satisfied).

But now consider our second question. Does a state that withholds weapons merely allow harm? The answer to this question depends on what we mean by "withholds", and this in turn depends on the kind of arms transfer the state in question is eschewing. If a state withholds weapons from the Incumbent in the sense that it refrains from engaging in Foreign Military Sales, and a consequence of this is that the Incumbent is unable to fend off the Challenger, it is plausible to hold that the state is, indeed, merely allowing harm to occur. This form of withholding is an omission, rather than an act; a mere denial of benefits. By withholding weapons in this way, a state behaves in an entirely passive manner. But things look different when a state withholds weapons by declining to issue an export license to a private firm that wishes to supply the Incumbent with arms. When a state refuses to issue an export license for a particular sale, this amounts to the state informing the relevant arms company that if it attempts to make the sale, it will be coercively prevented from doing so, and subjected to legal penalties. Thus, when a state refuses to issue an export license, it does not merely deny benefits; rather, it commits to actively preventing a transaction that could otherwise have gone ahead. ${ }^{7}$ And when a state prevents an arms sale, with the result that the would-be recipients of the sale are 
unable to defend themselves against wrongful aggression, this cannot be interpreted as a case of merely allowing (rather than doing) harm.

The upshot of these reflections is that the distinction between doing and allowing harm can at best ground an objection to (i) and (iii); it cannot ground an objection to (ii) and (iv). How else might (ii) and (iv) be challenged? One might claim that the Incumbent, by virtue of being oppressive, lacks legitimacy, and that the war it wages could therefore not be just. The Incumbent, one might claim, has forfeited its right to rule, and it has thereby forfeited the right to wage defensive wars (Luban, 1980, pp. 164-166). We can distinguish between two versions of this argument. The first, which we can call the No Claim Objection, targets (iv). According to this version of the argument, while legitimate states can have a claim-right to wage defensive wars, illegitimate states have no such right. Put differently, the suggestion is that while legitimate states have a right that can, at the very least, impose upon others a negative duty to refrain from interfering with their prosecution of a defensive war, illegitimate states lack that right. The objection continues: as oppressive states are illegitimate, they lack a right that could impose upon others a duty to refrain from interfering with their prosecution of a defensive war (e.g. by preventing them from acquiring the requisite weapons). So, while by refusing to license commercial sales to the Incumbent we thereby prevent it from waging an effective defensive war against wrongful aggression, the Incumbent has no right that could impose upon us a duty to act differently. 
Even if its conclusion is sound, this argument does not succeed as an objection to (iv). This is because the duty whose existence is posited by (iv) may be grounded in something other than the rights of the Incumbent. We may be duty-bound to issue an export license not because refraining from doing so would wrong the Incumbent's state officials, but because refraining from doing so would wrong its citizens. In fact, given that, on the most plausible account, a state's right to wage war is a right that is ultimately held by its citizens, and that its citizens have transferred to it (Fabre, 2014), it is natural to suppose that an illegitimate state retains a right to wage a defensive war that serves its citizens interests. For, why would its citizens revoke that right?

Now consider the second version of the argument currently under scrutiny, which we can call the No Liberty Objection, and which targets (ii). The first step in this objection maintains that oppressive states, by virtue of their illegitimacy, lack a liberty-right to wage defensive wars; that is, they have a duty not to wage defensive wars. The second step in the objection claims that it is impermissible to allow an agent to perform an action that that agent has a duty not to perform, at least when certain conditions hold - e.g. when the agent lacks a claim-right to perform the action in question (a "right to do wrong"); the action is especially egregious; and the costs to a third party of preventing the action are not unduly onerous. (As I believe this argument can be defeated irrespective of how it is formulated, I shall not dwell on specifying its optimal formulation.) It might then be said that the relevant 
conditions hold in Oppressors, and that it is therefore impermissible to license commercial sales to the Incumbent. This would mean that (ii) is false.

What should we say about this version of the objection? While it is true that a threat to its sovereignty does not automatically give an oppressive state a libertyright to defend itself, it is less plausible to claim that such a state lacks a liberty-right to defend itself against aggression that, if left unchecked, would produce injustice greater than that which characterizes the status quo (Caney, 2005, p. 204). To be sure, when a state performs acts that render it illegitimate, it thereby forfeits the right to exercise power in many of the ways in which power is typically exercised. But it is hard to see how one could defend the claim that, by virtue of mistreating its citizens, an illegitimate state is duty-bound to continue to neglect their interests by refusing to wage a defensive war against unjust aggression, a war that, perhaps for selfinterested reasons, it might be motivated to wage. Yet this is a claim that advocates of the No Liberty Objection are committed to endorsing.

At this point, it might be said that talk of states defending themselves or their citizens is misleadingly elliptical. When an illegitimate state wages a defensive war, it sends its subjects - the individual women and men it rules and oppresses - to fight and die. Illegitimate states (like their legitimate counterparts) do not defend their citizens, but rather command their citizens to defend themselves. And illegitimate states, it might be said, lack the authority to do that. 
But this objection is unpersuasive. While illegitimate states may lack the authority to order their citizens into battle in the sense that their citizens may have no obligation to comply with such orders, it is hard to deny that those citizens are nevertheless permitted to follow those orders in cases where they are the targets of unjust aggression. The citizens of illegitimate states have a right to defend themselves, their families, and their compatriots against unjust aggressors, and they may reasonably believe that participating in their country's armed forces is the best way to do so. Refusing to issue an export license to the Incumbent would deny its citizens the opportunity to participate in an effective defensive war against wrongful aggression, and we are yet to uncover an argument that could justify that denial.

So, in cases where withholding weapons from an oppressive regime would undermine its ability to repel an even more oppressive aggressor, we cannot justify a decision to withhold weapons (when this means refusing to issue an export license) by appealing to the distinction between doing and allowing harm, or to the fact that oppressive regimes lack legitimacy. Of course, this does not mean that, in such cases, arming oppressive regimes is always permissible. Notice that real-world cases that are otherwise similar to Oppressors often differ in one of three important respects. First, in civil wars, there is often a multiplicity of groups competing for power, and while one or more of those groups may threaten to impose a regime that is even worse than the one currently in place, others may be considerably more benign. (This appears to be the situation in the ongoing Syrian Civil War, in which the Assad 
regime is opposed both by genocidal fundamentalists like ISIL, and by ostensibly progressive groups such as the Syrian Democratic Forces.) When this is the case, we can intervene by supporting one of the more favourable groups. In such scenarios, it will often be impermissible to support the regime rather than one of its more benign rivals. ("Often" rather than "always" because the more benign rivals may sometimes lack the capacity to achieve a just victory. Their war may lack a reasonable chance of success, for example.) As I mentioned earlier, our assessment of a proposed arms transfer to an outlaw state must have a comparative element; we must ask how the proposal fares against other available options.

Second, an essential feature of Oppressors is that withholding weapons will undermine the ability of the Incumbent to wage a successful defensive war; the provision of weapons is crucial to tipping the balance in its favour. It should go without saying that this feature will not always characterize conflicts that are otherwise like the one I have been considering. There is a subclass of cases in which the incumbent regime requires our assistance in order to prevail, and a further subclass in which the assistance needed must come in the form of weapons. Sometimes it will be possible to tip the balance in favour of the incumbent regime without providing it with tools that can be used for oppressive ends, e.g. by providing it with intelligence that will enable it to locate insurgent bases. This point, like the previous one, drives home the fact that, in situations that are otherwise 
similar to Oppressors, there will often be a wider range of interventionist strategies from which to choose.

Third, I said that transferring weapons to the Incumbent, and thereby enabling it to fend off the Challenger, would simply preserve the status quo; I suggested that after the Challenger had been defeated, things would carry on in much the same way as they had before. But, sometimes, providing weapons to an oppressive regime will enable it to become more oppressive. In some cases like the one I have described, the Incumbent's rule may be less oppressive than the Challenger's promises to be not because the former has less oppressive ambitions, but simply because it is not sufficiently powerful to realize its ends. But providing the Incumbent with arms may bolster its power, and thereby enable it to tighten its stranglehold on the populace. If supplying weapons to the Incumbent can be expected to make it as oppressive as the Challenger, then the case for arms transfers collapses.

The considerations adduced in the last three paragraphs narrow the space in which the presumption against arming outlaw states can be overturned, and it is important to recognize that fact. But we have not succeeded in identifying an argument that demonstrates that (ii) and (iv) are never defensible claims. I will return to the case for (ii) and (iv) presently, but first there is a subsidiary matter that must be addressed. 
We should recall the point made earlier that the precise nature of the kind of case I have been considering will vary depending on how certain details are filled in. There are cases where the outcome of the conflict will affect not just the degree, but also the distribution, of oppression among the population, and there are cases where it will not. The most problematical scenario is one in which some individuals would be better-off under the Challenger's rule than they are under the Incumbent's rule, even though the Challenger's rule would be all-things-considered more oppressive than the status quo. Such a scenario would obtain if there were individuals who are oppressed by the Incumbent but who would not be oppressed by the Challenger. It could also obtain if the Challenger would oppress everyone (equally), while the Incumbent oppresses only a small minority. Under such conditions, the Challenger could be more oppressive by virtue of the fact that it seeks to oppress a larger number of people, even if it will oppress everyone less severely than the Incumbent oppresses a minority. While a lesser-evil justification for transfers can remain in this kind of scenario (because the Challenger is still more oppressive, all-thingsconsidered), the lesser-evil involved is greater than in cases where everyone is better-off under the Incumbent's rule.

In cases where there are individuals who would be better-off under the Challenger's rule, it is tempting to think that a state that transfers weapons, and thereby preserves the power of the Incumbent, acquires special responsibilities to those who are worse-off under the Incumbent's rule. We might believe that by 
preserving the subordinate position of the oppressed without making them betteroff than they would otherwise have been, the exporting state acquires a special duty to work to end their oppression.

But is this really plausible? Consider an analogous case.

Flood I: Heavy rain fall regularly causes a river to burst its banks and flood Town A. A sympathetic third party, Anita, draws up plans to redirect the water so that it instead floods Town B, which has a higher population and weaker flood defences. Reasonably believing that this would be unjust, I block the proposal, and thereby become implicated in the continued plight of Town A.

By blocking the proposal, do I thereby acquire special duties to Town A, duties that go beyond those I owe, say, to Town C, which also suffers from regular flooding? If I have to choose between assisting Town A and assisting Town C, should my decision hinge on the fact that I am "complicit" in Town A's plight, rather than on other considerations, regarding, for example, who has the greater need, or whom I can assist more effectively? It seems to me that it should not. Harm was inevitably going to befall someone, no one was liable to bear - or deserving of - the harm in question, and all I have done is act to prevent an agent from substituting a greater harm (to be imposed on one set of individuals) for a lesser harm (imposed on a different set). Given that there is no justification for this substitution - whereas there is a (lesserevil) justification for preserving the status quo - it is hard to see how claims for 
compensatory assistance could arise. The same is true in the case of a state that transfers weapons to the Incumbent under the conditions I have described. While it is plausible to hold that there are (general) duties to assist victims of oppression, it is less plausible to hold that the allocation of those duties should track facts about the kind of "complicity" involved in the case under scrutiny. The oppressed can make claims against us (and others) qua victims of oppression, but not qua victims of the particular kind of intervention described.

The issues considered in the previous three paragraphs are orthogonal to the central thrust of our discussion, but addressing them has provided resources with which to settle a matter that I have so far left open, namely, whether (ii) should be supplemented with (iv). Consider a variation on the thought-experiment introduced a moment ago.

Flood II: The same as Flood I, except that Bernard forbids me from intervening. I seek Bernard's permission to act, and permission is withheld. Given that no alternative action is taken, the water is redirected, and Town B is flooded instead of Town A.

Should we say that Bernard was merely permitted to grant me permission to act, or that he was also duty-bound to do so? In the absence of any alternative plan to block Anita's water-redirection proposal, it seems that Bernard was duty-bound. By withholding permission, Bernard acts in a way that facilitates Anita's substitution of 
a greater harm for a lesser harm, a substitution for which there is no justification; he stops me from preventing that substitution.

If Flood II is analogous to Oppressors in relevant respects, and if we are confident that, in the former case, Bernard is duty-bound to grant me permission to act, then we should also hold that, in the latter case, the state is duty-bound to issue an export license. The Challenger seeks to substitute a greater harm for a lesser harm, a substitution for which there is no justification. An arms firm then proposes to prevent (or contribute to the prevention of) that substitution. If the state refuses to issue an export license, it stops the firm in question from preventing the substitution. It enables the substitution to go ahead; it facilitates the Challenger's implementation of a greater harm.

Notice that the duty posited in (iv) is easier to defend than the duty posited in (iii). This is because the former, unlike the latter, is a negative duty. While (iii) holds that the state is duty-bound to provide benefits, (iv) holds that the state is dutybound only to refrain from preventing third parties from providing benefits. This follows from my analysis of the sense in which refusing to issue an export license counts as "withholding" arms. Notice, too, that, in many cases, one will not be able to contest (iv) by appealing to the onerousness of the posited duty. This is because the costs involved in discharging that duty will often be minimal. It might be said that, because issuing an export license implicates them in wrongdoing, the duty posited in (iv) requires state officials to act in a manner that compromises their moral 
integrity (Cf. Williams, 1973, pp. 98-99). But two responses are available here. First, authorizing one agent to sell the tools that a second agent may use to inflict wrongful harms, and doing so purely in order to ensure that a third agent does not substitute those wrongful harms for greater ones, is far removed from the kind of complicity in wrongdoing that we usually expect to pose large threats to one's integrity. Second, as should be clear from what was argued earlier, state officials would also become implicated in wrongdoing if they withheld arms. If they refuse to issue an export license, they become implicated in the harms that will be inflicted by the Challenger, harms that could have been averted had an export license been granted.

One significant cost that may sometimes be borne by a state that issues an export license is a risk of terroristic reprisals. Individuals who are oppressed by the Incumbent (or who belong to the same ethnic, religious, or national community as those who are oppressed), may be aggrieved by the provision of support to the Incumbent, and may seek violent revenge. This seems unlikely in cases where all of the Incumbent's citizens stand to be made worse-off by the Challenger, and it might be less likely than in cases where state officials negotiate the sale themselves, rather than merely permitting private firms to make the sale. Nevertheless, when there is a sizeable risk of "blowback", this could justify (or at least excuse) declining to grant an export license. 
Let me conclude this section by suggesting that when attempting to determine whether a particular arms transfer is permissible, the first question we should ask is not "Is the recipient oppressive?", but rather "What effect will the sale have on the incidence and degree of oppression?" The consideration that motivates this suggestion is the one that we have examined, namely, that arms transfers to an oppressive regime may sometimes reduce the overall incidence or degree of oppression by enabling the regime in question to repel an even more oppressive rival. This can be true even if the sale contributes to oppression in one sense by sustaining an oppressive status quo. But there is also a second consideration that one might adduce in support of my suggestion, namely, that arms sales to oppressive regimes sometimes do not contribute to oppression at all. This thought can be illustrated with an example. The US subjects certain prisoners to sustained periods of solitary confinement, a practice which critics argue is a form of torture, and we might think that this fact justifies regarding the US as an oppressive regime (Gawande, 2009). But it is natural to doubt whether arms sales contribute to the maintenance of this practice; the suspension of arms transfers, it seems reasonable to suppose, would not precipitate the abolition of solitary confinement.

However, it is important to observe that arms sales can contribute to oppression in a variety of different ways, some of which are subtler than others. The most obvious way in which arms transfers can contribute to oppression is by making available the tools used by oppressive regimes against their people. We are inclined 
to say that arms transfers to the US do not contribute to the maintenance of oppressive practices because those transfers do not contribute in this way. It is not as though, in the absence of arms transfers, the US would lack the means of oppression. But arms transfers can also contribute to oppression in another way. The maintenance of trade relations can express certain attitudes; it can communicate to a trading partner that it is regarded as a respected member of the international community, that its status is not undermined by any of its internal practices. In this way, the maintenance of trade relations can be interpreted as a tacit endorsement of a trading partner's internal practices. Put differently, the maintenance of trade relations can be regarded as contributing to oppressive practices when the suspension of those relations (or the threat of suspension) could be used to incentivize reform of such practices. Of course, these considerations do not differentiate the arms trade from other, more conventional, forms of trade, and we may sometimes have all-things-considered reasons to maintain certain forms of trade with oppressive regimes. The point I am currently making, and with which I shall close this section, is simply that we must adopt a broad understanding of what it means for a sale to contribute to oppression.

\section{Aggressive Regimes}

So far I have considered the morality of selling weapons to oppressive regimes. I turn now to the morality of selling weapons to aggressive regimes. When one regime poses a wrongful threat to another, we have a pro tanto duty to refrain from 
providing it with weapons. If we were to provide weapons, we would facilitate, and become complicit in, any wrongful harms that the regime inflicts. This duty is undoubtedly violated frequently. But are there any conditions under which it could be overridden? The strongest case for arming an aggressive regime mirrors the strongest case for arming an oppressive regime: it arises in situations where the regime's own legitimate security interests are threatened. As I mentioned above, it does not follow from the fact that a regime wrongfully aggresses against others that it will never be a victim of wrongful aggression itself. We saw in the previous section that we cannot oppose transfers to outlaw states by claiming that, when a government withholds an export license, it merely allows harm to occur, or on the grounds that outlaw states lack legitimacy. I also stressed that when an arms transfer is proposed, its merits and demerits must be compared to other available modes of intervention. But let us now consider in more detail the conditions that would have to be satisfied in order for arms transfers to an aggressive regime to be justifiable.

Consider the following scenario.

Aggressors: A regime (the Claimant) is the target of wrongful aggression, and the following further conditions also hold: (i) the Claimant has acted aggressively in the past, but is not currently engaged in aggression; (ii) it is liable to act aggressively again in the future; (iii) providing the Claimant with weapons is the only viable way of enabling it to defend itself and its citizens; (iv) providing weapons can be expected to enhance the threat that the 
Claimant wrongfully poses to others (the Third Parties); (v) the Claimant's citizens are in no way culpable for its leaders' actions; and (vi) the defensive war that the Claimant intends to wage can be expected to satisfy the requirements of justice (at least if arms transfers are made). ${ }^{8}$

It is under these conditions that the question of whether arms transfers are permissible is most difficult to answer. When any one of conditions (i)-(vi) is altered, the question becomes easier, because the case for transfers is either weakened or strengthened. However, as I explain below, altering the conditions in a way that would strengthen the case for transfers cannot be done without either departing from reality, or jettisoning the scenario's key characteristic (namely, the fact that the regime in question is aggressive). Therefore, the conditions that I have described actually characterize the circumstances under which the strongest case for arming an aggressive regime can be made.

Consider the first condition, according to which, while the Claimant has acted aggressively in the past, it is not presently engaged in wrongful aggression. If the Claimant were presently engaged in wrongful aggression, the case for permitting the sale of weapons would be weakened by two considerations. First, the continued exercise of wrongful aggression would pose a challenge to the suggestion that the Claimant requires additional weapons in order to satisfy its citizens' legitimate security interests. In the absence of additional weapons, it could simply redeploy the weapons that it is currently using for wrongful purposes. Second, by continuing to 
engage in wrongful aggression, the Claimant is declining an available opportunity to demonstrate to potential trading partners that it will not use their weapons in a wrongful manner.

Now consider the second condition. If the Claimant had acted aggressively in the past but were not liable to act aggressively again in the future - if it had, say, reached a peace agreement with its past adversaries - the concern about arms transfers facilitating aggression would be less acute, and the case for permitting weapons transfers would be strengthened. With regards to the third condition, if providing weapons were not the only viable way of enabling the Claimant to defend itself and its citizens, then we could justify a refusal to supply weapons by committing to other forms of assistance, forms which may lack the downside of bolstering the threat that the recipient poses to Third Parties. Even if the available alternatives were less effective than the provision of arms, their adoption could sometimes be justified on the grounds that it is a happy medium between (a) arming the Claimant (and thereby endangering Third Parties) and (b) doing nothing (and thereby neglecting the interests of the Claimant's citizens). ${ }^{9}$ So, when the third condition is not satisfied, the case for transfers is weakened.

The absence of the fourth condition would strengthen the case for transfers. If providing weapons would not be likely to enhance the threat that the Claimant poses to Third Parties - if, say, weapons could be magically teleported back to their distributors, or remotely disabled - the case for withholding weapons would be 
substantially diminished. Let us now consider the fifth condition, according to which the Claimant's citizens are not culpable for their leaders' actions. This condition will often be satisfied - especially when the regime in question is not only aggressive but also authoritarian - and, when it is, the case for transfers will be stronger than it would be otherwise. When the fifth condition is satisfied, a decision to withhold weapons will appeal to facts about activity that the Claimant has engaged in that are independent of, and perhaps contrary to, its citizens' wishes and interests; the decision to reject arms-requests grounded in the legitimate security-interests of the people will be motivated not by considerations about what the people have done, but rather by considerations about what their government has done. By contrast, when citizens have actively supported or encouraged a wrongfully aggressive foreign policy, we can justify our decision to decline weapons-requests by telling the people: "not only do we mistrust your government; we mistrust you. Through your past actions, you have revealed yourself to be an untrustworthy and irresponsible polity." I do not claim that this consideration is decisive, only that it weakens the case for arms transfers.

Finally, let us consider the sixth condition. Even if the Claimant has a just cause for war (self-defence), the war it proposes to wage may nevertheless fail to be just overall. This would be the case if, say, it failed to discriminate between legitimate and illegitimate targets, or if the harms it proposed to inflict were expected to be excessive in relation to those it intended to prevent. If the sixth 
condition is not satisfied, the case for arms transfers will be weakened. One especially egregious feature of recent British and American arms sales to Saudi Arabia is that they continued in the face of the desert kingdom's systematic violation of the rules of war.

Deviating from one (or both) of conditions (ii) and (iv) would strengthen the case for arms transfers, while deviating from any one of the remaining four conditions would weaken the case. But notice what deviation from (ii) and (iv) involves. Deviating from (ii) - the Claimant is liable to act aggressively in the future - amounts to saying that the Claimant is not actually aggressive. And it is hard to see how deviation from (iv) - providing weapons can be expected to enhance the threat that the Claimant wrongfully poses to others - could currently be possible. Weapons cannot be magically teleported back to their distributors if and when they are misused; nor can they be remotely disabled: so the scenario I have described is the one in which the strongest case for arming an aggressive regime could actually arise. Let us now return to this case.

In the scenario I described, it is especially difficult to establish whether arms transfers should be permitted. More specifically, it is especially difficult to adjudicate between the interests of two sets of individuals: the legitimate security-based interests of the Claimant's citizens, and the legitimate security-based interests of Third Parties who are threatened by the Claimant. If we were to withhold weapons, by refusing to issue an export license, how could we try to justify this to the 
Claimant's citizens? We might say that the Claimant's citizens should direct their complaints at their government: if their government had not engaged in unacceptable behaviour in the past, it would not have lost our trust, and we would be able to provide weapons without worrying that, by doing so, we would be jeopardizing the interests of Third Parties. One problem here is that, as we have already noted, we are penalizing the people for the behaviour of their government. Another problem is that there may be nothing that the government can do in the short-term (in the time-frame in which it requires weapons) to win back our trust. (Remember that, in the case we are imagining, the Claimant is not currently actively engaged in aggressive behaviour.) By saying that we would provide weapons if only the regime could demonstrate its trustworthiness, we may be asking for the impossible.

If we were to go ahead and transfer weapons, how could we try to justify this to the Third Parties who are wrongfully threatened by the Claimant? We might be able to say that there is only a risk that the Claimant will use our weapons to harm them, whereas it is certain that the Claimant's citizens will be harmed unless we permit the transfers (see, relatedly, Pattison, 2015, p. 462). But if the risk is high enough, or if the risk actually materializes, this is hardly sufficient to vindicate our decision. We might commit to protecting the threatened Third Parties from any future aggression that our weapons make possible, but then it seems that we have simply transferred (some of) the harm that we have helped to create to the women 
and men who comprise our armed forces, and that, in turn, will have to be justified to them. But perhaps there are ways to insulate the Third Parties from harm without relying on our armed forces. If we currently engage in cooperative enterprises with the Claimant, we can threaten to terminate this cooperation if it engages in future aggression. If we are not currently engaged in such enterprises, we can issue conditional offers of cooperation. We could also threaten to terminate any cooperation we engage in with the Claimant's allies if aggressive policies are pursued. If these allies are sufficiently powerful or valuable, they may be able to influence the Claimant's behaviour, and the threat of withdrawn cooperation may provide them with adequate incentive to do so.

When the other relevant conditions obtain, this kind of strategy offers the best chance of vindicating arms sales to aggressive regimes, and, in principle at least, this strategy can succeed. The issue can be framed in terms of proportionality, as that term is understood in just war theory. According to the sixth condition that characterizes Aggressors, the war that the Claimant proposes to wage will, amongst other things, be proportionate. But we also need to know whether our act of arming the Claimant will itself be proportionate - that is, whether or not the harms associated with providing arms will be excessive in relation to the good we can reasonably hope to achieve - and that question cannot be answered simply by considering whether the Claimant's war will be proportionate; we also need to consider the harms that will or might be imposed upon the Third Parties. It is 
tempting to think that the (dis)proportionality of a particular act, $\mathrm{P}$, is determined independently of our subsequent actions. But the actions that we perform subsequent to $\mathrm{P}$ can help to determine whether $\mathrm{P}$ is itself proportionate. Providing arms to the Claimant is permissible if, among other things, doing so satisfies the proportionality criterion, but whether that criterion is satisfied will depend upon how we act subsequent to providing arms. This is because our subsequent actions will affect the degree of harm associated with our initial act, the harm that will be weighed against the good outcomes associated with our initial act in the calculation that will determine that act's proportionality. The provision of arms may be proportionate if we subsequently engage in the kinds of activities described above (e.g. threatening to terminate cooperation if the Claimant pursues aggressive policies), which can mitigate the harms associated with arms provision, but disproportionate if we do not engage in those activities. If this is the case, an exporting state will have to engage in those activities in order to justify its decision to provide weapons.

One final issue that needs to be addressed is whether arming the Claimant is merely permitted, or also required. One feature that distinguishes Aggressors from Oppressors is a larger element of uncertainty. In the latter case, the Incumbent is currently imposing upon its citizens an observable degree of oppression, and I stipulated that we are able to compare that degree of oppression to that which is threatened by the Challenger. In the former case, by contrast, the Claimant is not 
currently engaged in aggressive behaviour, and we are forced to speculate about the harms that it may subsequently inflict on Third Parties. As we saw, if the provision of weapons enables the Claimant to inflict harms that turn out to be disproportionate, the exporting state will acquire remedial duties, and discharging those duties may be costly, e.g. if doing so requires deploying the armed forces, or abandoning cooperative practices with other states. Moreover, it seems plausible to hold that sometimes these costs (and the risk of having to bear them) will be large enough to rule out the existence of a duty to arm. In such cases, the provision of arms will be permissible (provided that the exporting state is committed to discharging any remedial duties that this act engenders), but not required.

\section{Conclusion}

I want to conclude with some qualificatory addenda. I have suggested that the presumption against arming outlaw states can sometimes be overturned. But I should stress that my argument does not have the effect of exonerating Britain, the US, and other western states that regularly provide weapons to oppressive and aggressive regimes. I suggested that arms transfers to such regimes can be permissible, and sometimes required, but only under certain conditions. The conditions I identified are too special for my account to ground anything like a general permission to arm outlaw states, but not so special as to render permissible transfers to such states a practical impossibility. During WWII, the US Lend-Lease policy sanctioned arms transfers to the Soviet Union, and these could potentially be 
justified by the arguments I have supplied. The Soviet Union was an oppressive and aggressive regime, but (i) arms transfers were necessary to enable the Red Army to resist the greater oppression that would otherwise have been imposed by the Nazis, and (ii) after the end of WWII, and throughout the Cold War, the US acted to bolster the strength of those states that were vulnerable to Soviet aggression. (The case is complicated by the fact that weapons transfers were approved at a time when the Soviets were engaged in ongoing aggression, illegally occupying territory in a number of neighbouring states. This fact (along with more ideological considerations) made many US politicians reluctant to extend arms transfers to the Soviet Union.)

The conclusion that it can sometimes be permissible to arm outlaw states is not a comfortable one to embrace. When we witness states providing weapons to oppressive and aggressive regimes, we tend to assume that, by doing so, they are forfeiting their status as members in good standing in the international community and, typically, they are. But recognizing that arms transfers to outlaw states can sometimes be justified coheres with widely shared views about just war. A commonly held view among those who write about the ethics of war is that military action in a just war can be permissible even if it foreseeably kills individuals who have not made themselves liable to be killed. Provided that the deaths are not intended, and that they are proportionate, their infliction can be justifiable. But, then, it would be strange to conclude that while killing innocents by dropping bombs on them can be 
justified in this way, contributing to their deaths (or to the infliction of other burdens) by exporting weapons cannot.

Still, it is incumbent upon me to finish with a cautionary remark: while there are conditions under which it can be permissible, even obligatory, to arm outlaw states, those conditions are exceptional, and rarely obtain. This means that the regular arming of oppressive and aggressive regimes by Britain, the US, and others is simply one further example of the myriad ways in which the governments of these countries casually and callously disregard the most stringent requirements of morality.

\section{References}

Buchanan, A. (2013) "The Ethics of Revolution and Its Implications for the Ethics of Intervention", Philosophy EPublic Affairs 41 (4) (2013): 291-323.

Camus, A. (2000 [1942]) The Myth of Sisyphus. London: Penguin Books.

Caney, S. (2005) Justice Beyond Borders. Oxford: Oxford University Press.

Christensen, J. (2015) “Weapons, Security, and Oppression: A Normative Study of International Arms Transfers", Journal of Political Philosophy, 23 (1), 23-39.

Christensen, J. (2017) Trade Justice. Oxford: Oxford University Press.

Cohen, G. A (2011) "Freedom and Money" in Michael Otsuka (ed.) On the Currency of Egalitarian Justice, and Other Essays in Political Philosophy. Princeton, NJ: Princeton University Press.

DeGrazia, D. (2016) "Handguns, Moral Rights, and Physical Security", Journal of Moral Philosophy, 13 (1), 56-76.

Fabre, C. (2010) “In Defence of Mercenarism”, British Journal of Political Science, 40 (3): 539-59

Fabre, C. (2014) Cosmopolitan War. Oxford: Oxford University press.

Finlay, C. J. (2015) Terrorism and the Right to Resist: A Theory of Just Revolutionary War. Cambridge: Cambridge University Press.

Gawande, A. (2009) "Hellhole", The New Yorker, available at: http://www.newyorker.com/magazine/2009/03/30/hellhole.

James, A. (2012) Fairness in Practice: A Social Contract for a Global Economy. New York: Oxford University Press.

Lafollette, H. (2000) “Gun Control”, Ethics, 110 (2), 263-281.

Luban, D. (1980) "Just War and Human Rights", Philosophy and Public Affairs, 9 (2), 160-81.

MacAskill, E. (2016) "UN report into Saudi-led strikes in Yemen raises questions over UK role", The Guardian, available at: https://www.theguardian.com/world/2016/jan/27/un-report-into-saudi-ledstrikes-in-yemen-raises-questions-over-uk-role.

McMahan, J. (2009) Killing in War. Oxford: Oxford University Press. 
McMahan, J. (2010) "Humanitarian Intervention, Consent, and Proportionality" in N. A. Davis, R. Keshen, and J. McMahan (eds.), Ethics and Humanity: Themes from the Philosophy of Jonathan Glover. New York: Oxford University Press.

Pattison, J. (2014) The Morality of Private War: The Challenge of Private Military and Security Companies. Oxford: Oxford University Press.

Pattison, J. (2015) “The Ethics of Arming Rebels", Ethics \& International Affairs, 29 (4), 455-471.

Quinn, B and Booth, R. (2011) "Britain cancels Bahrain and Libya arms export licences", The Guardian, available at: https://www.theguardian.com/uk/2011/feb/18/military-bahrain?INTCMP=SRCH.

Risse, M. (2007) "Fairness in Trade I: obligations from trading and the Pauper-Labor Argument", Politics, Philosophy and Economics, 6 (3), 355-377.

Sandel, M. (2012). What Money Can't Buy: The Moral Limits of Markets. London: Penguin Books.

Satz, D. (2010) Why Some Things Should Not be for Sale: The Moral Limits of Markets. New York: Oxford University Press.

Shiffrin, S. V. (1999) "Wrongful Life, Procreative Responsibility, and the Significance of Harm", Legal Theory, 5 (2), 117-148.

Stohl, R and Grillot, S. (2009) The International Arms Trade. Cambridge: Polity Press.

Tan, A. T. H. (ed.) (2010) The Global Arms Trade: A Handbook. New York: Routledge.

Townsend, M and Boffey, D. (2014) "UK condemned over arms sales to repressive states", The Guardian, available at: https://www.theguardian.com/world/2014/nov/08/uk-condemned-arms-salesrepressive-states.

Williams, B. (1973) "A Critique of Utilitarianism", in J. J. C. Smart and Bernard Williams Utilitarianism: For and Against. Cambridge: Cambridge University Press, 1973.

An earlier version of this paper was presented at a workshop on trade justice hosted by Harvard University. I am grateful to participants at this event for their valuable feedback, and especially to Helena de Bres and Mathias Risse, who provided excellent comments in their capacity as discussants. A very early draft was presented at a workshop hosted by Pompeu Fabra University. I received helpful feedback from my discussant, David Axelsen, and also from the other participants. Paul BouHabib and Tom Parr have each provided helpful written comments. In addition, I have benefitted from helpful discussions with Paul and Tom, and also with Chris Armstrong, Catriona Macinnon, Zosia Stemplowska, and Patrick Tomlin. Finally, I am grateful for the feedback provided by two anonymous reviewers for Political Studies.

${ }^{1}$ The only article-length treatment of the issue is Christensen (2015). A revised and extended version of this discussion appears in Christensen $(2017,11-31)$. The related matter of arming rebel groups is addressed in Pattison (2015).

2 This body of literature includes Fabre (2010), Buchanan (2013), Pattison (2014); and Finlay (2015).

${ }^{3}$ For a discussion of the first set of scope-restrictions, see Christensen $(2015,27-28)$.

${ }^{4}$ The term "outlaw state" is borrowed from Rawls (1999).

${ }^{5}$ In this paper, I do not distinguish between permission and justification. Rather, I use the two concepts interchangeably. 
${ }^{6}$ The Challenger may be more oppressive either in the sense that it will oppress a larger number of people, or in the sense that the oppression it inflicts will be more severe. That we can anticipate how oppressive the Challenger's rule will be is not an unrealistic stipulation. Suppose the Challenger is ISIL. We know enough about ISIL - about what it believes in, and about how it has governed in the territories that it has managed to conquer - to be able to predict with reasonable accuracy what future ISIL rule would look like.

${ }^{7}$ Cf. the account of how a lack of money undermines negative liberty in Cohen (2011).

${ }^{8}$ The parenthetical qualification is included in acknowledgement of the fact that arms sales could transform an unjust war into a just one. This would be the case if the war was unjust simply by virtue of lacking a reasonable chance of success, and if arms transfers could bolster the recipient's prospects of victory.

${ }_{9}$ We have to tread carefully here. If available alternatives are "less effective", this might mean that the war lasts longer than it otherwise would have, and that more innocent lives are lost. But the point of adopting alternative strategies is to reduce the threat that the Claimant poses to innocent Third Parties. If the harms engendered by pursuing a strategy other than arms provision are expected to be greater than the harms that the Claimant could inflict on Third Parties, if armed, then the justification for pursuing that strategy is undermined. 